\title{
THE RELATIONSHIPS OF MOTIVATION AND SANCTION WITH HAND HYGIENE COMPLIANCE AMONG HEALTH WORKERS AT DR. PIRNGADI HOSPITAL, MEDAN, NORTH SUMATERA
}

\author{
Sondang Simanjuntak, Ida Yustina, Zulfendri
}

\author{
Masters Program in Public Health, Universitas Sumatera Utara
}

\begin{abstract}
Background: Hand hygiene is described by many health care workers as the single most important tool in preventing the spread of health care-associated infections between patients. Washing hands before and after patient contact seems like a simple solution to prevent the spread of bacteria between patients. Most hospitals have hand hygiene policies in place that guide their employees to do just that. But this policy is not always complied with. This study aimed to determine the associations of presence of sanction and motivation with hand hygiene compliance among health workers at Dr. Pirngadi Hospital, Medan.

Subjects and Method: A cross sectional study was conducted at Dr. Pirngadi Hospital, Medan, North Sumatera. A sample of 33 health workers were selected for this study by exhaustive sampling. The dependent variable was hand hygiene compliance. The independent variables were sanction and motivation. The data were collected by questionnaire and analyzed by a mulitiple logistic regression.

Results: Hand hygiene compliance was associated with the presence of sanction $(\mathrm{OR}=3.44 ; 95 \% \mathrm{CI}=1.22$ to $4.95 ; \mathrm{p}=0.041)$ and motivation $(\mathrm{OR}=4.77 ; 95 \% \mathrm{CI}=$ 2.52 to 6.30; $\mathrm{p}=0.029$ ).

Conclusion: Hand hygiene compliance is associated with sanction and motivation.
\end{abstract}

Keywords: hand hygiene, compliance, sanction, motivation

\section{Correspondence:}

Sondang Simanjuntak. Masters Program in Public Health, Universitas Sumatera Utara, Medan, North Sumatera. Email: sondangstarlyn@gmail.com.

Mobile: 081361773441. 